\title{
Front Matter: Volume 9181
}

, "Front Matter: Volume 9181," Proc. SPIE 9181, Light Manipulating Organic Materials and Devices, 918101 (10 November 2014); doi:

10.1117/12.2176705

SPIE Event: SPIE Organic Photonics + Electronics, 2014, San Diego, California, SPIE. United States 


\title{
PROCEEDINGS OF SPIE
}

\section{Light Manipulating Organic Materials and Devices}

\author{
Jean-Michel Nunzi \\ Editor
}

\section{0-21 August 2014}

San Diego, California, United States

Sponsored and Published by

SPIE 
The papers included in this volume were part of the technical conference cited on the cover and title page. Papers were selected and subject to review by the editors and conference program committee. Some conference presentations may not be available for publication. The papers published in these proceedings reflect the work and thoughts of the authors and are published herein as submitted. The publisher is not responsible for the validity of the information or for any outcomes resulting from reliance thereon.

Please use the following format to cite material from this book:

Author(s), "Title of Paper," in Light Manipulating Organic Materials and Devices, edited by JeanMichel Nunzi, Proceedings of SPIE Vol. 9181 (SPIE, Bellingham, WA, 2014) Article CID Number.

ISSN: 0277-786X

ISBN: 9781628412086

Published by

SPIE

P.O. Box 10, Bellingham, Washington 98227-0010 USA

Telephone +1 3606763290 (Pacific Time) · Fax +1 3606471445

SPIE.org

Copyright $@ 2014$, Society of Photo-Optical Instrumentation Engineers.

Copying of material in this book for internal or personal use, or for the internal or personal use of specific clients, beyond the fair use provisions granted by the U.S. Copyright Law is authorized by SPIE subject to payment of copying fees. The Transactional Reporting Service base fee for this volume is $\$ 18.00$ per article (or portion thereof), which should be paid directly to the Copyright Clearance Center (CCC), 222 Rosewood Drive, Danvers, MA 01923. Payment may also be made electronically through CCC Online at copyright.com. Other copying for republication, resale, advertising or promotion, or any form of systematic or multiple reproduction of any material in this book is prohibited except with permission in writing from the publisher. The CCC fee code is 0277-786X/14/\$18.00.

Printed in the United States of America.

Publication of record for individual papers is online in the SPIE Digital Library.

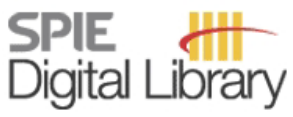

SPIEDigitalLibrary.org

Paper Numbering: Proceedings of SPIE follow an e-First publication model, with papers published first online and then in print and on CD-ROM. Papers are published as they are submitted and meet publication criteria. A unique, consistent, permanent citation identifier (CID) number is assigned to each article at the time of the first publication. Utilization of CIDs allows articles to be fully citable as soon as they are published online, and connects the same identifier to all online, print, and electronic versions of the publication. SPIE uses a six-digit CID article numbering system in which:

- The first four digits correspond to the SPIE volume number.

- The last two digits indicate publication order within the volume using a Base 36 numbering

system employing both numerals and letters. These two-number sets start with 00, 01, 02, 03, 04, $05,06,07,08,09,0 A, 0 B \ldots$. OZ, followed by 10-1Z, 20-2Z, etc.

The CID Number appears on each page of the manuscript. The complete citation is used on the first page, and an abbreviated version on subsequent pages. Numbers in the index correspond to the last two digits of the six-digit CID Number. 


\title{
Contents
}

\author{
$\checkmark \quad$ Authors \\ vii Conference Committee \\ ix Direct electronic probing of biological complexes formation (Organic Photonics + \\ Electronics Plenary Paper) [9183-402]
}

\section{SESSION 1 NONLINEAR ABSORPTION EFFECTS}

918104 Engineering the ground- and excited-state absorption spectra of broadband reverse saturable absorbers [9181-3]

918105 Synthesis of dual NIR two-photon absorptive [60]fullerenyl multiadducts for nonlinear lighttransmittance reduction application [9181-4]

\section{SESSION 2 DYNAMICS OF LIGHT-MATTER INTERACTIONS}

9181 OA Quantifying singlet fission in novel organic materials using nonlinear optics [9181-9]

\section{SESSION 3 ORGANIC PHOTOREFRACTIVE MATERIALS}

9181 OC Enhanced photoconductivity by melt quenching method for amorphous organic photorefractive materials [9181-11]

9181 OD Large optical second harmonic generation in a low-bandgap polymer [9181-12]

9181 OE Dynamic amplification of light signals in photorefractive ferroelectric liquid crystals [9181-13]

\section{SESSION 4 LIGHT-TRIGGERED AND LIGHT-ACTUATED MATERIALS}

9181 OG Arbitrary 2D GRIN lens fabrication in diffusive photopolymers [9181-15]

$9181 \mathrm{OH} \quad$ Tunable non-pixelated spatial polarization shaping including an integrated optical addressing unit [9181-16]

$91810 \mathrm{~J} \quad$ Nonlinear solid-state filter based on photochromism induced by 2-photon absorption in a dye-doped sol-gel [9181-18] 
9181 OL Molecular magneto-optics (Keynote Presentation) [9181-20]

$91810 \mathrm{~N}$ Chiral supramolecular assemblies from achiral and chiral molecules investigated by second harmonic generation at the air-water interface (Invited Paper) [9181-22]

\section{SESSION 6 ENHANCED OPTICAL INTERACTIONS}

9181 OP Optical properties of $\mathrm{Alq}_{3}$ films and $\mathrm{Alq}_{3} /$ plasmonic heterostructures (Invited Paper) [9181-24]

$91810 Q \quad$ Plasmonic mode interactions with organic semiconductor gain media in nano-confined geometries (Invited Paper) [9181-25]

\section{SESSION 7 ENGINEERING OF THE LINEAR AND NONLINEAR OPTICAL PROPERTIES OF ORGANICS}

9181 OU Design and fabrication strategies for high transparency polymer nanocomposites with dynamic tunable optical response (Invited Paper) [9181-29]

POSTER SESSION

918110 A toy model for the nonlinear optical response of molecules with modulated conjugation [9181-36]

918111 Design and simulation of metal-insulator-metal nanoresonators for color filter applications [9181-37]

918112 Light transmission with self-assembly DNA monolayers through D-shaped optical fiber [9181-39]

918113 Miniaturized low-power electro-optic modulator based on silicon integrated nanophotonics and organic polymers [9181-40]

$918116 \quad$ Improving optical limiting of cw lasers with fullerene functionalized gold nanoparticles [9181-43]

918117 Strong photoluminescence characteristics of sulforhodamine B attached on photonic crystal [9181-45] 


\title{
Authors
}

Numbers in the index correspond to the last two digits of the six-digit citation identifier (CID) article numbering system used in Proceedings of SPIE. The first four digits reflect the volume number. Base 36 numbering is employed for the last two digits and indicates the order of articles within the volume. Numbers start with 00, 01, 02, 03, 04, 05, 06, 07, 08, 09, 0A, 0B...0Z, followed by 10-1Z, 20-2Z, etc.

\author{
Ajward, M., OP \\ Anderson, Ken, OG \\ Banerjee, Saswatee, 11 \\ Bar, Galit, 0J \\ Bekere, Laura, 0J \\ Benichou, E., ON \\ Bensalah-Ledoux, A., ON \\ Berkelbach, Timothy, OA \\ Bockstaller, Michael R., OU \\ Bozio, Renato, 16 \\ Brevet, Pierre-François, ON \\ Bruyère, $\mathrm{A} ., \mathrm{ON}$ \\ Busby, Erik, OA \\ Campos, Luis, OA \\ Canteenwala, Taizoon, 05 \\ Chen, Quanhang, 10 \\ Chen, Ray T., 13 \\ Chiang, Long, 05 \\ Cooper, Thomas, 05 \\ Dang, Alei, OU \\ De Filippo, Christian Corrado, 16 \\ Ferry, Michael J., 04 \\ Frare, Maria Chiara, 16 \\ Fujihara, T., OC \\ Gangopadhyay, Palash, OL \\ Gao, Q., OP \\ Giordano, Francesco, ix \\ Goodman, Sarah, $0 Q$ \\ Grinvald, Shmuel, 0J \\ Guy, L., ON \\ Guy, S., ON \\ Gvishi, Raz, 0J \\ Hablani, Surbhi, 10 \\ Hagan, David, OJ \\ Hosseini, Amir, 13 \\ Hu, Honghua, OJ \\ Hui, Chin Ming, OU \\ Hwang, Jihyun, 12 \\ Ishibashi, K., OC \\ Jagadish, C., OP \\ Jen, Alex K.-Y., 13 \\ Jeon, Seaho, 05 \\ Ji, Wei, 05 \\ Jung, Woohyun, 12 \\ Kang, Kwang-Sun, 17 \\ Kaveh, M., OP \\ Khodorkovsky, Vladimir, 0J \\ Kim, Byoung-Ju, 17 \\ Kinashi, K., OC
}

Koeckelberghs, Guy, OD, OL
Kong, Byung-Joo, 12
Kumar, Bharat, OA
Li, Jie, 10
Lokshin, Vladimir, OJ
Luo, Jingdong, 13
Macchia, Eleonora, ix
Maggini, Michele, 16
Magliulo, Maria, ix
Manoli, Kyriaki, ix
Matyjaszewski, Krzysztof, OU
McLeod, Robert R., OG
Miller, John, OA
Mott, Andrew G., 04
Naka, Yumiko, OE
Nuckolls, Colin, OA
O'Carroll, Deirdre M., OQ
Oh, Kyunghwan, 12
Osten, Wolfgang, OH
PalazO, Gerardo, ix
Park, Sung Ha, 12
Paulson, Bjorn, 12
Pei, Chengkui, O4
Perez-Moreno, Javier, 10
Persoons, André P., OL
Pritchett, Timothy M., 04
Reichman, David, OA
Rutloh, Michael, OH
Sakai, W., OC
Sasaki, Takeo, OE
Sassa, T., OC
Schaal, Frederik, OH
Schmitzer, H., OP
Sfeir, Matthew Y., OA
Shensky, William M., III, O4
Sigalov, Mark, OJ
Signorini, Raffaella, 16
Son, Jun Young, 12
Strum, Galit, OJ
Stumpe, Joachim, OH
Sun, Wenfang, O4
Tal, Amir, OJ
Tan, Loon-Seng, 05
Torsi, Luisa, ix
Tsujimura, S., OC
Tsutsumi, Naoto, OC
Urness, A. C., OG
Vanbel, Maarten K., OD
Vandendriessche, Stefaan, OD


Van Stryland, Eric W., OJ

Verbiest, Thierry, OD

Wagner, H. P., OP

Wang, Min, 05

Wang, $X ., O P$

Weber, Verena, 16

Weidenfeld, Susanne, $\mathrm{OH}$

Wickremasinghe, N., OP

Willot, Pieter, OD

Wilson, William L., OG

Wu, Qin, OA

$X i a$, Jianlong, OA

Yaffe, Omer, OA

Zhang, Xingyu, 13

Zhao, Peng, $0 \mathrm{~J}$

Zhu, Xiaoyang, OA

Proc. of SPIE Vol. 9181 918101-6

Downloaded From: https://www.spiedigitallibrary.org/conference-proceedings-of-spie on 25 Apr 2023 Terms of Use: https://www.spiedigitallibrary.org/terms-of-use 


\section{Conference Committee}

Symposium Chair

Zakya H. Kafafi, National Science Foundation, ret (United States)

Conference Chair

Jean-Michel Nunzi, Queen's University (Canada)

Conference Co-Chairs

Jon A. Schuller, University of California, Santa Barbara (United States)

Rachel Jakubiak, Air Force Research Laboratory (United States)

Manfred Eich, Technische Universität Hamburg-Harburg (Germany)

Conference Program Committee

Dean R. Evans, Air Force Research Laboratory (United States)

Theodore G. Goodson III, University of Michigan (United States)

Mark G. Kuzyk, Washington State University (United States)

Charles Y. C. Lee, Air Force Office of Scientific Research (United States)

Kwang-Sup Lee, Hannam University (Korea, Republic of)

Aristides Marcano, Delaware State University (United States)

André P. Persoons, Katholieke Universiteit Leuven (Belgium)

Jayan Thomas, CREOL, The College of Optics and Photonics, University of Central Florida (United States)

Naoto Tsutsumi, Kyoto Institute of Technology (Japan)

\section{Session Chairs}

1 Nonlinear Absorption Effects

Soo Young Park, Seoul National University (Korea, Republic of)

2 Dynamics of Light-Matter Interactions

David S. Hagan, McMaster University (Canada)

3 Organic Photorefractive Materials

André P. Persoons, Katholieke Universiteit Leuven (Belgium)

$4 \quad$ Light-Triggered and Light-Actuated Materials

Jon A. Schuller, University of California, Santa Barbara (United States) 
5 Magneto-Chiral Interactions

Zouheir Sekkat, Moroccan Foundation for Advanced Science, Innovation and Research (Morocco)

$6 \quad$ Enhanced Optical Interactions

Alex K. Y. Jen, University of Washington (United States)

7 Engineering of the Linear and Nonlinear Optical Properties of Organics

Pierre-François Brevet, Université Claude Bernard Lyon 1 (France) 